\title{
PEMBAYANGAN MENTAL AWAL MAHASISWA CALON GURU MATEMATIKA TERHADAP PENJUMLAHAN DAN PENGURANGAN FUNGSI REAL
}

\author{
Darmadi $^{1}$, Benny N. Trisna ${ }^{2}$ \\ ${ }^{1}$ FKIP Universitas PGRI Madiun, ${ }^{2}$ STKIP PGRI Banjarmasin \\ ${ }^{1}$ darmadi.mathedu@unipma.ac.id, ${ }^{2}$ benny@stkipbjm.ac.id
}

\begin{abstract}
Abstrak: Pembayangan mental grafik fungsi merupakan modalitas utama mahasiswa calon guru matematika dalam memahami konsep-konsep terkait fungsi real. Beberapa konsep matematika sangat memerlukan pembayangan mental tentang penjumlahan dan pengurangan fungsi. Paper ini membahas pembayangan mental awal mahasiswa calon guru matematika terhadap penjumlahan dan pengurangan fungsi real. Data diperoleh melalui wawancara berbasis tugas. Sebanyak 20 subjek penelitian dipilih dari mahasiswa semester 7 program studi pendidikan matematika FKIP Universitas PGRI Madiun yang belum pernah mendapatkan materi atau penjelasan tentang visualisasi penjumlahan dan pengurangan grafik fungsi. Hasil penelitian menunjukkan bahwa terdapat 7 (tujuh) bentuk pembayangan mental awal mahasiswa calon guru matematika terhadap penjumlahan dan pengurangan fungsi real.
\end{abstract}

\section{Kata Kunci: pembayangan mental, penjumlahan dan pengurangan fungsi real}

Pembayangan mental merupakan suatu modalitas individu untuk memahami suatu konsep. Seperti ketika akan mendefinisikan segitiga atau segi empat, atau bahkan mendefinisikan hewan seperti gajah atau kuda, pada umumnya, individu memunculkan gambaran tentang segitiga, segi empat, gajah, atau kuda dalam pikiran. Gambaran segitiga, segi empat, gajah, atau kuda dalam pikiran merupakan contoh pembayangan mental. Pembayangan mental sering juga disebut dengan gambaran mental, visualisasi, pencitraan, imagery, bayangan, imajinasi, dan sebagainya. Hasil penelitian awal Darmadi (2011) menunjukan bahwa pembayangan mental mahasiswa dalam pembelajaran analisis real masih kurang.
Pembayangan metal individu dapat ditingkatkan dari tidak ada pembayangan mental menjadi ada, dari pembayangan mental yang kurang menjadi lengkap, pembayangan mental yang kurang benar menjadi benar, dan pembayangan mental yang kurang sempurna menjadi lebih sempurna. Pembayangan mental dapat diadakan dengan memperhatikan dan memahami benda-benda atau grafik-grafik fungsi. Pembayangan mental dapat dibenarkan melalui proses pembelajaran. Menurut Darmadi (2012), pembelajaran matematika perlu dikembangkan dengan menggunakan visualisasi untuk memperkaya pembayangan mental siswa atau mahasiswa.

Pembayangan mental yang benar dan sempurna sangat dibutuhkan bagi mahasiswa calon guru matematika. Jika pembayangan 
mental tidak benar, maka dapat mengakibatkan pemahaman konsep yang berkenaan dengan pembayangan mental tersebut menjadi tidak benar juga. Jika pembayangan mental tidak sempurna, maka dapat menyebabkan pemahaman terhadap konsep yang berkenaan dengan pembayangan mental tersebut juga tidak sempurna. Pembayangan mental yang tidak benar perlu dibenarkan dan pembayangan mental yang tidak sempurna perlu disempurnakan supaya konsep yang berkenaan dengan pembayangan mental tersebut benar dan sempurna. Hasil penelitian Darmadi (2015) menunjukan bahwa terjadi proses memunculkan, mengolah, dan memanfaatkan pembayangan mental dalam memahami definisi. Dalam proses mengolah pembayangan mental terjadi proses membenarkan dan menyempurnakan pembayangan mental.

Pembayangan mental terhadap penjumlahan dan pengurangan fungsi sangat dibutuhkan untuk memahami konsep-konsep yang berkenaan dengan penjumlahan dan pengurangan fungsi. Konsep-konsep yang berkenaan penjumlahan dan pengurangan fungsi adalah adalah penerapan konsep limit, turunan, dan integral. Tanpa pembayangan mental, konsep penjumlahan dan pengurangan fungsi hanya menjadi hafalan tanpa makna. Hasil penelitian yang telah dilakukan Darmadi (2016) bahwa dalam menyelesaikan masalah secara visual juga terjadi pemrosesan pembayangan mental dengan tahapan seperti teori Tall yaitu memahami, merencanakan, melaksanakan, dan memeriksa kembali.

Paper ini membahas pembayangan mental awal mahasiswa calon guru matematika terhadap penjumlahan dan pengurangan fungsi. Kekayaan pembayangan mental mahasiswa terhadap penjumlahan dan pengurangan fungsi sangat diperlukan untuk memahami konsep-konsep matematika lain yang berkenaan dengan penjumlahan dan pengurangan fungsi real.

\section{Metode Penelitian}

Untuk mendapatkan data pembayangan mental awal mahasiswa calon guru matematika terhadap penjumlahan dan pengurangan fungsi, digunakan metode penelitian kualitatif. Subjek penelitian dipilih dengan kriteria belum pernah mendapatkan materi atau penjelasan tentang visualisasi penjumlahan dan pengurangan grafik fungsi. Subjek penelitian adalah mahasiswa semester 7 program studi pendidikan matematika FKIP Universitas PGRI Madiun.

Data diambil dengan menggunakan teknik wawancara berbasis tugas. Tugas mahasiswa adalah menggambarkan grafik fungsi $f+g$ dan $f-g$ dimana grafik fungsi $f$ dan $g$ diberikan sebagai berikut.

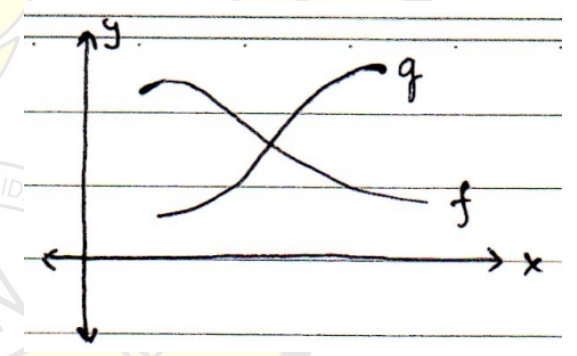

Mahasiswa menyediakan dan menjawab pada lembar jawaban secara langsung sebelum dilakukan wawancara oleh peneliti.

Data yang diperoleh dikumpulkan, dikategorikan, dan dianalisis. Hasil kategorisasi dinyatakan sebagai kategori pembayangan mental mahasiswa. Hasil analisis berikutnya digunakan sebagai bahan pembahasan hasil penelitian dan kesimpulan yang mendsekripsikan bentuk kategori pembayangan mental awal mahasiswa calon guru matematika terhadap penjumlahan dan pengurangan fungsi. 


\section{Hasil Penelitian dan Pembahasan}

\section{A. Hasil Penelitian}

Terdapat 20 responden atau subjek dalam penelitian ini. Berdasarkan data yang diberikan responden, diperoleh 7 kategori pembayangan mental awal mahasiswa calon guru matematika terhadap penjumlahan dan pengurangan fungsi sebagai berikut.

1. Kategori pertama

Kategori pertama pembayangan mental awal mahasiswa calon guru matematika terhadap penjumlahan dan pengurangan adalah sebagai berikut.

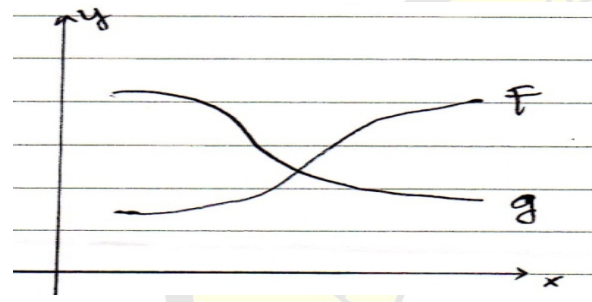

dan

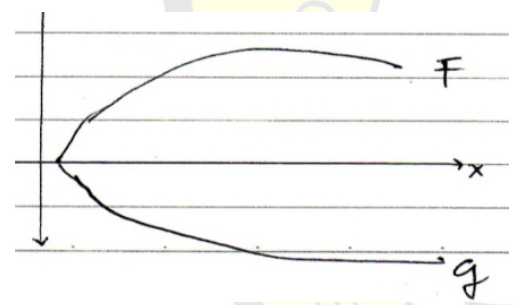

Terdapat 5\% mahasiswa dengan pembayangan mental awal kategori pertama seperti yang digambarkan tersebut. Mahasiswa tidak memberi alasan yang jelas alasan terbentuknya gambaran atau pembayangan mental tersebut. Hal itu terjadi karena mahasiswa belum mengetahui gambaran penjunmlahan dan pengurangan fungsi.

2. Kategori kedua

Kategori kedua pembayangan mental awal mahasiswa calon guru matematika terhadap penjumlahan dan pengurangan adalah sebagai berikut.

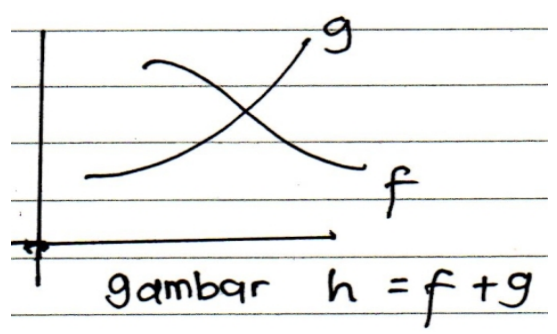

dan

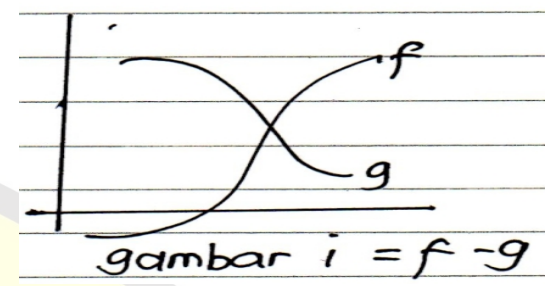

Terdapat $45 \%$ mahasiswa dengan pembayangan mental awal kategori kedua seperti yang digambarkan tersebut. Mahasiswa tidak memberi alasan yang jelas alasan terbentuknya gambaran atau pembayangan mental tersebut. Hal itu terjadi karena mahasiswa belum mengetahui gambaran penjunlahan dan pengurangan fungsi.

3. Kategori ketiga

Kategori ketiga pembayangan mental awal mahasiswa calon guru matematika terhadap penjumlahan dan pengurangan adalah sebagai berikut.
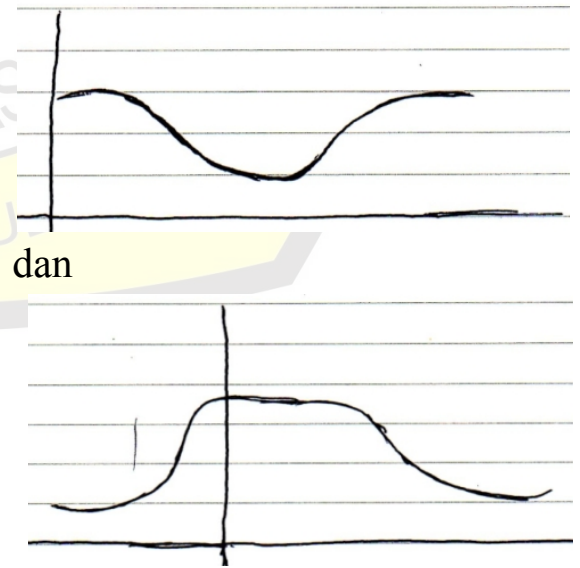

Terdapat $15 \%$ mahasiswa dengan pembayangan mental awal kategori ketiga seperti yang digambarkan tersebut. Mahasiswa tidak memberi alasan yang jelas alasan terbentuknya gambaran atau 
pembayangan mental tersebut. Hal itu terjadi karena mahasiswa belum mengetahui gambaran penjunmlahan dan pengurangan fungsi.

4. Kategori keempat

Kategori keempat pembayangan mental awal mahasiswa calon guru matematika terhadap penjumlahan dan pengurangan adalah sebagai berikut.

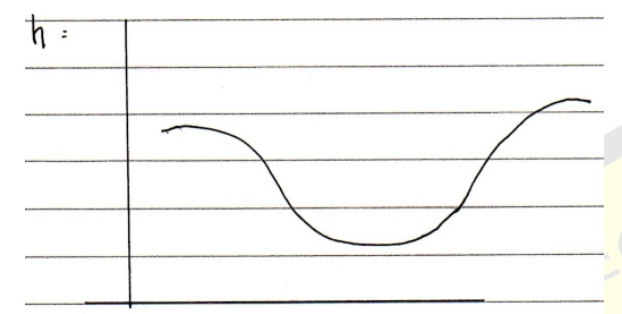

dan

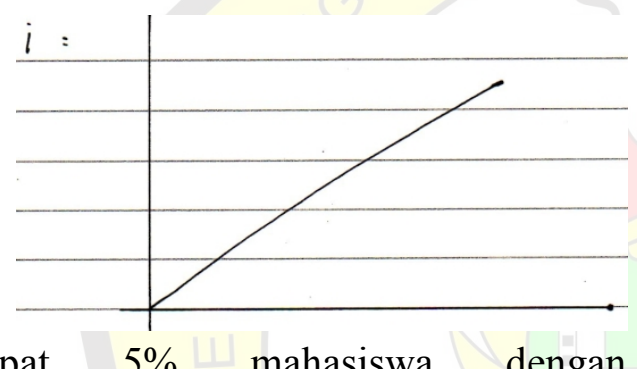

Terdapat 5\% mahasiswa dengan pembayangan mental awal kategori keempat seperti yang digambarkan tersebut. Mahasiswa tidak memberi alasan yang jelas alasan terbentuknya gambaran atau pembayangan mental tersebut. Hal itu terjadi karena mahasiswa belum mengetahui gambaran penjunmlahan dan pengurangan fungsi.

5. Kategori kelima

Kategori kelima pembayangan mental awal mahasiswa calon guru matematika terhadap penjumlahan dan pengurangan adalah sebagai berikut.

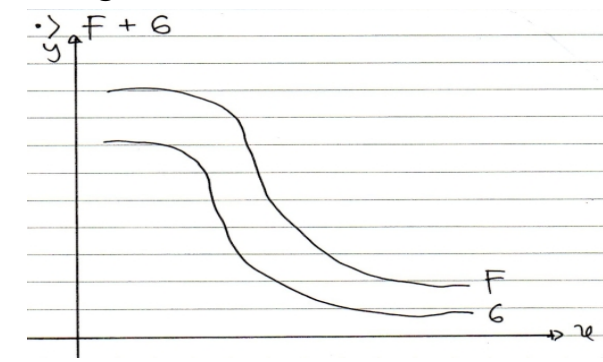

dan

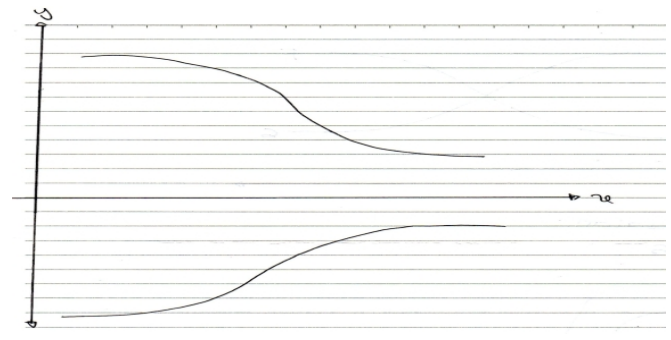

Terdapat 5\% mahasiswa dengan pembayangan mental awal kategori kelima seperti yang digambarkan tersebut. Mahasiswa tidak memberi alasan yang jelas alasan terbentuknya gambaran atau pembayangan mental tersebut. Hal itu terjadi karena mahasiswa belum mengetahui gambaran penjunmlahan dan pengurangan fungsi.

6. Kategori keenam

Kategori keenam pembayangan mental awal mahasiswa calon guru matematika terhadap penjumlahan dan pengurangan adalah sebagai berikut.

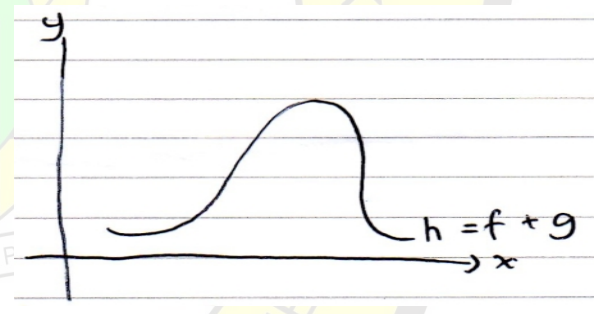

dan

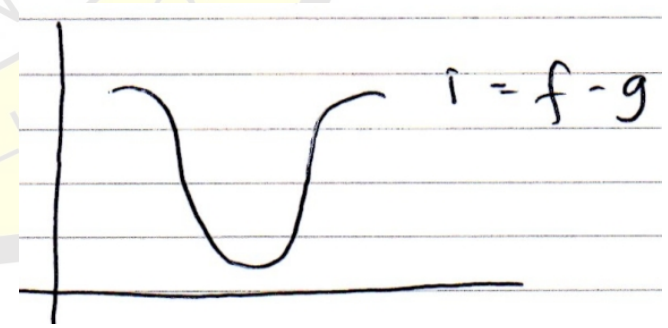

Terdapat $15 \%$ mahasiswa dengan pembayangan mental awal kategori keenam seperti yang digambarkan tersebut. Mahasiswa tidak memberi alasan yang jelas alasan terbentuknya gambaran atau pembayangan mental tersebut. Hal itu terjadi karena mahasiswa belum 
mengetahui gambaran penjunmlahan dan pengurangan fungsi.

7. Kategori ketujuh

Kategori ketujuh pembayangan mental awal mahasiswa calon guru matematika terhadap penjumlahan dan pengurangan adalah sebagai berikut.

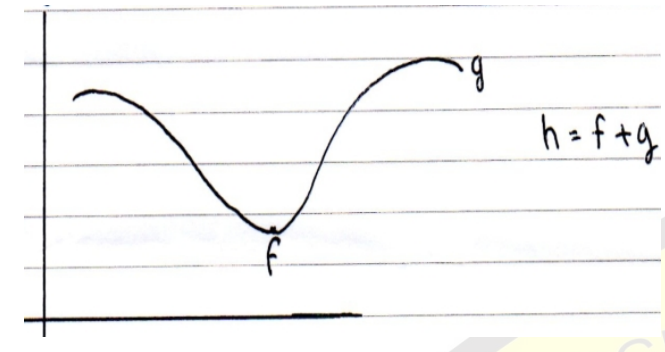

dan

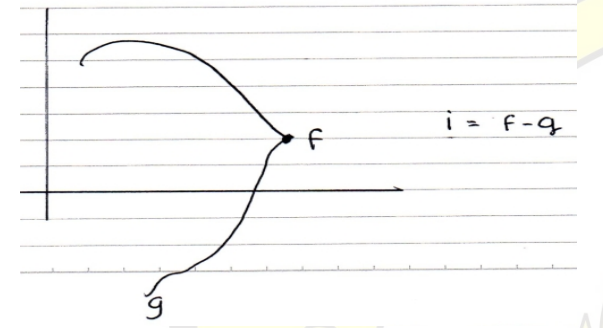

Terdapat $10 \%$ mahasiswa dengan pembayangan mental awal kategori ketujuh seperti yang digambarkan tersebut. Mahasiswa tidak memberi alasan yang jelas alasan terbentuknya gambaran atau pembayangan mental tersebut. $\mathrm{Hal}$ itu terjadi karena mahasiswa belum mengetahui gambaran penjunmlahan dan pengurangan fungsi.

\section{B. Pembahasan}

Temuan tentang macam-macam pembayangan mental awal mahasiswa calon guru matematika terhadap penjumlahan dan pengurangan fungsi, menunjukkan miskinnya pembayangan mental mahasiswa calon guru matematika.

Materi fungsi telah diberikan sejak SMP (Sekolah Menengah Pertama) atau yang sederajat. Fungsi adalah relasi yang menghubungkan setiap anggota domain tepat satu (secara unik) ke anggota kodomain.
Fungsi dapat dinyatakan sebagai pasangan berurutan. Fungsi umumnya dinotasikan dengan huruf kecil seperti $f, g, h$, atau $i$.

Dua atau lebih fungsi dapat dioperasikan seperti operasi penjumlahan dan pengurangan. Misalkan penjumlahan fungsi $f$ dan fungsi $g$ biasa didefiniskan dengan $(f+$ $g)(x)=f(x)+g(x)$ dengan $D_{f+g}=D_{f} \cap$ $D_{g}$, pengurangan fungsi $f$ dan fungsi $g$ biasa didefinisikan dengan $(f-g)(x)=f(x)-$ $g(x)$ dengan $D_{f-g}=D_{f} \cap D_{g}$. Sehingga gambaran penjumlahan fungsi $f$ dan $g$ untuk permasalahan di atas adalah sebagai berikut.

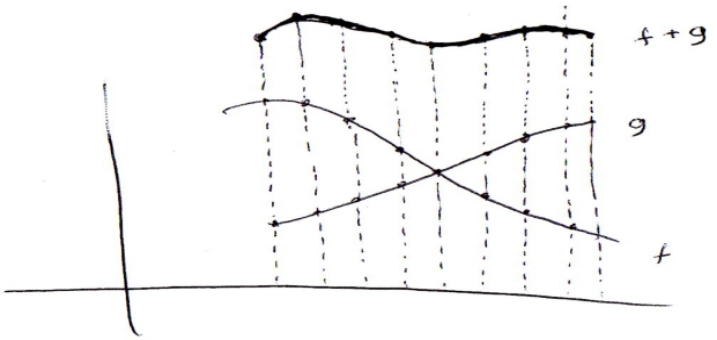

Gambaran pengurangan fungsi $f$ dan $g$ untuk permasalahan di atas adalah sebagai berikut.

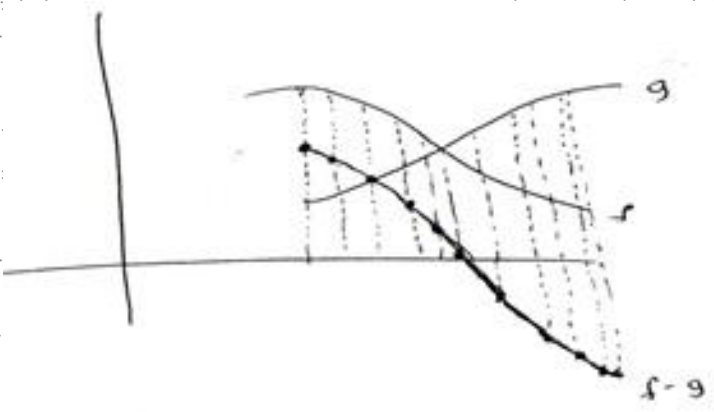

Gambaran penjumlahan maupun pengurangan fungsi $f$ dan $g$ memberikan gambaran hasil sekaligus konsep pembatasa domain sehingga hasil penjumlahan dan pengurangan fungsi dapat terjadi.

\section{Simpulan dan Saran}

\section{Simpulan}


Berdasarkan uraian di atas, dapat diperoleh kesimpulan sebagai berikut.

1. Terdapat 7 (tujuh) kategori pembayangan mental awal mahasiswa terhadap penjumlahan dan pengurangan fungsi yang diperoleh mahasiswa dengan argumentasi atau alasan yang jelas.

2. Mahasiswa calon guru matematika masih lemah atau kurang kaya dalam hal pembayangan mental terhadap penjumlahan dan pengurangan fungsi
Berdasarkan Perbedaan Gender". Disertasi, UNESA, Surabaya

Darmadi. 2016. "Profil Berpikir Visual Mahasiswa Calon Guru Matematika dalam Menyelesaikan Masalah Trigonometri", Jurnal Math Educator Nusantara, ISSN: 2459-97345, Volume 2 Nomor 2, Hal 1-93, Mei 2016, Program Studi Pendidikan Matematika, FKIP Universitas Nusantara PGRI Kediri.

\section{Saran}

Saran yang dapat disampaikan bagi mahasiswa dan dosen adalah sebagai berikut.

1. Mahasiswa perlu memperkaya diri dengan tidak terlalu fokus ke formalitas namun perlu juga menggunakan gambaran atau pembayangan mental.

2. Dosen atau guru sebaiknya tidak terlalu fokus ke formalitas, namun perlu menjelaskan konsep-konsep yang ada dengan gambaran yang jelas.

\section{Daftar Pustaka}

Darmadi. 2011. "Imajeri Mahasiswa Dalam

Pembelajaran Analisis Real (Studi

Kasus Di IKIP PGRI MADIUN)".

Makalah disajikan pada Seminar

Nasional UNY, Jogjakarta, 3

Desember 2011

Darmadi. 2012. "Membangun Pembelajaran

Matematika yang Menyenangkan dengan Visualisasi”. Makalah disajikan pada Seminar Nasional UNY, Jogjakarta, 24 Maret 2012

Darmadi. 2015. "Profil Berpikir Visual Mahasiswa Calon Guru Matematika dalam Memahami Definisi Formal 